\title{
DISFEMISME DALAM PERSPEKTIF SEMANTIK, SOSIOLINGUISTIK, DAN ANALISIS WACANA
}

\author{
Elisa Nurul Laili
}

elisa_nurullaili@yahoo.co.id

Hasyim Asyari University

Tebuireng Jombang, Indonesia

\begin{abstract}
Dysphemism is an expression with connotations that are offensive either about the denotatum or the audience. It is used to talk about one's opponents, things one wishes to show disapproval of, and things one wishes to be seen to downgrade. The topic of dysphemism is crucial to investigate because dysphemism is the infraction of the rules of politeness that deals with the matters of face and face effects.This research uses descriptive qualitative method. The approach used in this research is library research. Data taken from taking notes and observation.This article is written to explain dysphemism in the perspective of Semantics, Sociolinguistics, and Discourse Analysis.
\end{abstract}

Keywords: Dysphemism, Politeness, Semantics, Sociolinguistics, Discourse Analysis

\section{PENDAHULUAN}

Bahasa telah berevolusi dari masa ke masa. Sebagai produk budaya ciptaan atau hasil kreasi manusia, bahasa berkembang dengan berbagai penggunaan yang bervariasi. Bahasa digunakan untuk mengekspresikan ide, pikiran, perasaan dan emosi. Bahasa, dalam artian yang sesungguhnya, adalah merupakan realisasi atau representasi pemikiran manusia secara lisan.

Semakin lama semakin bertambah fungsi bahasa, yaitu tidak hanya digunakan untuk menjaga komunikasi antar manusia, tetapi juga digunakan untuk menghina, mengejek, merendahkan, atau bahkan membunuh musuh. Dengan demikian, dapat diketahui bahwa fungsi bahasa bervariasi tergantung oleh orang yang menggunakan bahasa tersebut. Hal inilah yang meyebabkan Allan dan Burrdige (2009) mengatakan bahwa bahasa dapat digunakan menjadi perisai dan senjata bagi para penggunanya, baik untuk merangkul kawan, maupun menghancurkan lawan.

Secara umum, bahasa digunakan sebagai alat komunikasi dan untuk membangun hubungan yang baik dengan sesama manusia. Menurut Nababan dalam Masrokhin (2002, h. 3-4) bahasa mempunyai beberapa fungsi yang lebih spesifik, yaitu sebagai alat perkembangan budaya, menjaga keberlangsungan budaya, dan temuan atas karakteristik dari suatu kebudayaan.

Bahasa mempunyai dua peran yang khusus dalam kehidupan manusia. Pertama berdasarkan skala atau jangkauan, dan kedua adalah berdasarkan ranah penggunaan. Berdasarkan skala atau jangkauan dapat dibedakan menjadi bahasa nasional dan bahasa komunitas. Sebagai bahasa nasional, fungsi bahasa adalah sebagai kebanggaan bangsa, persatuan, alat komunikasi resmi serta simbol identitas suatu negara. Sedangkan bahasa sebagai bahasa komunitas digunakan oleh kelompok kecil manusia, seperti kelompok etnis dalam suatu negara, suku, atau komunitas subkutltur sebagai simbol identitas kelompok mereka.

Berdasarkan ranah penggunaan, terdapat fungsi bahasa dalam ranah pendidikan, kebudayaan, dan individu. Penggunaan bahasa dalam ranah pendidikan adalah sebagai alat pemersatu bagi semua pelajar yang merupakan bagian dari 
masyarakat majemuk. Bahasa sebagai instrumen untuk memperoleh keuntungan materi, mendapat pekerjaan, dan sebagainya. Sebagai produk budaya, bahasa untuk menghargai dan menghormati masyarakat. Bahasa sebagai alat untuk mengungkapkan penalaran adalah peranan bahasa dalam penyampaian atau pengungkapan ide, pemikiran, pemahaman dan penciptaan konsep dengan logika sederhana.

Berdasarkan fungsi bahasa yang digunakan oleh individu, yakni bahwa bahasa digunakan berdasarkan keinginan penuturnya. Bahasa digunakan sebagai alat untuk memenuhi keinginan penuturnya, untuk berbagi pengetahuan, perasaaan dan pemikiran kepada sesama manusia. Selaras dengan Crystal (1987, h. 10), bahwa salah satu fungsi bahasa adalah untuk mengekspresikan emosi. Bahasa berfungsi sebagai alat untuk mengungkapkan ekspresi dan emosi manusia. Bahasa ditunjukkan ketika manusia marah, frustasi, takut, atau cinta dan kasih sayang. Ketika seseorang mengekspresikan kasih sayang, maka seseorang tersebut menunjukkan emosi yang positif. Tetapi ketika seseorang mengekspresikan kemarahana atau frustasi, maka seseorang tersebut menunjukkan emosi yang negatif. Emosi yang negatif ini biasanya menggunakan sumpah serapah atau makian. Disini, bahasa juga disebut memiliki fungsi ideasional.

Berdasarkan alasan terakhir, seseorang biasa menggunakan bahasa berdasarkan mood mereka. Oleh karena itu, bahasa mereka sangat dipengaruhi oleh emosi-emosi tadi. Bahasa yang digunakan bisa sangat baik dan sopan, biasanya juga sangat buruk, kasar, bahkan tidak sopan. Biasanya bahasa yang terpengaruh oleh emosi ini seringkali tidak dapat dikontrol oleh penuturnya.

Dari sini, perkembangan bahasa tidak hanya selalu lebih baik dari masa ke masa. Belakangan dapat dilihat bahwa penggunaan bahasa cenderung mengingkari kaidah-kaidah kesantunan dalam berbahasa. Istilah-istilah tabu, serapah, makian, vulgar, serta hujatan (bersifat keagamaan) yang harusnya dihindari pada masa lampau menjadi hal yang lumrah dan biasa dilakukan oleh masyarakat di masa sekarang. Beberapa orang menggunakannya untuk mengekspresikan kritik, protes dan cibiran kepada komunitas atau kelompok masyarakat tertentu. Mereka juga menggunakan bahasa tabu atau vulgar untuk menguatkan pernyataan mereka, atau bahkan menunjukkan solidaritas dalam ruang lingkup komunitas mereka.

Penggunaan bahasa baik berupa kata, frase, klausa atau kalimat yang kasar dan tidak sopan dan cenderung menyakitkan atau mengganggu pendengar atau audiens ini disebut disfemisme. Disfemisme menurut Allan and Burridge (1991, p. 2) adalah penggunaan bahasa kasar yang bertujuan sebagai senjata untuk melawan atau menaklukkan lawan, atau bahasa kasar yang diucapkan untuk mengekspresikan kemarahan dan frustasi.

Wijana (2008, h. 250) mengemukakan bahwa bahasa dikreasikan untuk melayani kebutuhan komunikatif manusia. Salah satunya yaitu sebagai sarana untuk mengekspresikan berbagai perasaan yang dialami oleh penuturnya, seperti perasaan senang, takut, kecewa, kesal, sedih, dan sebagainya. Dalam hal ini, Wijana menyebutkan bahwa bahasa dikatakan mengemban fungsi ekspresif (periksa Holmes, 1992, h. 286; Wijana, 1997, h. 28).

\section{Bentuk, Referensi, Tipe, Pembentukan dan Fungsi Disfemisme}

Disfemisme adalah ekspresi dengan konotasi yang menyakitkan bagi petutur (orang kedua), atau pendengar (orang ketiga), atau oleh keduanya, oleh sebab itu, maka sebaiknya digantikan dengan ungkapan yang lebih netral atau halus. Disfemisme digunakan untuk membicarakan lawan, barang, atau perbuatan yang ditentang oleh pembicara, sehingga dengan penggunaan disfemisme ini akan memperburuk (Allan dan Burrige, 1991, h. 26).

Penggunaan kata-kata atau frase-frase dan ungkapan kasar yang membuat pendengar merasa terganggu, risih dan tersakiti disebut disfemisme. Disfemisme adalah bahasa yang menyakitkan dan digunakan oleh pembicara sebagai senjata untuk menyerang lawan, atau untuk meluapkan kekecewaan, kemarahan dan emosi negatif (frustrasi). Untuk menghindari penyalahgunaan secara politis dan emosional, Allan dan Burridge menyarankan penutur untuk memilih alternatif yang netral. Menurut Allan dan Burridge, ada delapan tipe disfemisme: 
1) Istilah-istilah tabu yang digunakan untuk menyakiti, mengejek, memberi julukan, atau memaki, contoh organ tubuh yang menimbulkan nafsu birahi, atau digunakan untuk buang air kecil dan buang air besar, aktivitas-aktivitas yang meliputi organ di atas, zat yang dihasilkan organ-organ di atas, kematian, penyakit, makanan dan bau, julukan atau sapaan (Ketuhanan, kekerabatan, binatang).

Anderson dalam Karjalainen (2002, h. 17) menambahkan, dalam kebudayaan Barat, biasanya istilah tabu diperoleh dari hal-hal sebagai berikut: agama, cacat fisik dan mental, prostitusi, narkotika, dan kriminalitas.

2) Makian dan serapah yang cabul. Dalam hal ini, makian cabul termasuk disfemisme jika mengambil istilah yang berkaitan dengan penghujatan nama Tuhan dan istilah cabul. Memaki seseorang atau suatu hal bertujuan untuk menyakiti dan menghina objek yang dilecehkan, juga termasuk disfemisme. Contoh "Fuck you!", "Fuck! Aku tidak mencuri barangmu!"

Dalam hal ini, makian dan serapah juga termasuk disfemisme karena menyakiti orang yang dituju. Lebih lanjut, Linguis Swedia, Ljung (2006, h. 62-75) membagi sumpah serapah dengan kategori sebagai berikut:

Tabel 1. Motif Makian

\begin{tabular}{|c|c|}
\hline Motif Makian & Contoh \\
\hline Religius & “Christ", "Hell”, “Damn”, “Go to hell!” \\
\hline Skatologis & $\begin{array}{l}\text { "Shit", "Crap"," Ass", "Asshole", "Kiss } \\
\text { my ass!" }\end{array}$ \\
\hline Genital & $\begin{array}{l}\text { "Cock", "Dick"," Cunt,," You stupid } \\
\text { prick!" }\end{array}$ \\
\hline Seksual & $\begin{array}{l}\text { "Fuck", "Fucker", "Fucking", "I don't } \\
\text { give a fuck! ", "Screw you!" }\end{array}$ \\
\hline Sodomi & "Up yours!", “Up your ass!” \\
\hline Ibu & $\begin{array}{l}\text { "Motherfucker", "Son of a Bitch", } \\
\text { "Bastard" }\end{array}$ \\
\hline Prostitusi & “Whore", "Pimp" \\
\hline Masturbasi & “Wanker", "Jerk" \\
\hline Binatang & "Dirty pig", "Stupid cow" \\
\hline Kematian & "Eat shit and die!" \\
\hline
\end{tabular}

Sesuai dengan hasil penelitian Wijana (2008), kata-kata kasar dalam bahasa Jawa diperoleh dari tindakan atau keadaan yang berkenaan dengan berbicara, makan, minum, tidur, pergi dan mati. Selain itu, bagian-bagian tubuh yang digunakan untuk berkata kasar yaitu kepala, mata, mulut, kaki, perut dan pantat. Selanjutnya, juga diperoleh dari perbandingan tindakan yang dilakukan binatang, keadaan fisik yang tidak menyenangkan, dan benda-benda yang dekat dengan lingkungannya.

Selanjutnya, menurut Wijana dan Rohmadi (2006), referensi makian dalam bahasa Indonesia dapat diperoleh dari keadaan fisik, binatang, benda, bagian tubuh, kekerabatan, makhluk halus, aktivitas, profesi dan seruan. Sedangkan bentuk makian dalam bahasa Indonesia terdiri atas kata, frasa, dan klausa. Lebih lanjut, Wijana dan Rohmadi (2006) menjelaskan bahwa substansi yang sering dijadikan sasaran makian yaitu kebodohan, keabnormalan, sesuatu yang terkutuk atau dilarang oleh agama, ketidakberuntungan, sesuatu yang menjijikkan, dan sesuatu yang mengganggu hidup manusia.

Dalam hal ini, jenis makian yang dipresentasikan oleh Montagu, yakni abusive swearing (makian), blasphemy (hujatan), cursing (kutukan), swearing (sumpah), obscenity (kecarutan), dan expletive (lontaran/seruan) termasuk ke dalam disfemisme. Montagu menjelaskan makian sebagai tindakan verbal yang mengekspresikan perasaan agresif yang mengikuti perasaan frustasi yang dalam atau berlebihan yang tercermin dalam kata-kata atau tuturan yang mengandung asosiasi emosional yang kuat (Indrawati, 2006, h. 2325).

3) Perbandingan manusia dengan hewan yang dianggap memiliki perilaku negatif.

Contoh: memanggil seseorang dengan sebutan babi karena tidak sopan, ular karena licik atau tidak bisa dipercaya, buaya karena suka mempermainkan wanita, keledai karena bodoh, kerbau karena malas.

4) Julukan atau sapaan disfemistis yang diambil dari karakter fisik yang terlihat, sehingga petutur dianggap seolah menjadi orang yang abnormal. Contoh: Hei, Gendut! Hei, Botak!

5) Makian dengan menggunakan istilah yang diperoleh dari abnormalitas mental. Contoh: Dasar idiot! Autis lo! Otak udang!

6) -IST disfemisme (rasis, dll.) yang berfungsi sebagai ejekan. Contoh: Cina! Blacks! Nigger! 
7) Istilah-istilah yang menunjukkan ejekan atau tidak hormat yang menggunakan nada tidak hinaan pada karakter orang yang dituju. Contoh: Pelacur, pecundang.

Meskipun begitu, masih banyak ekspresi disfemistis yang masih belum dituliskan oleh Allan dan Burridge, misalkan ekspresi disfemistis dalam berbagai sosial media, poster, maupun ungkapan-ungkapan yang termasuk cyber bullying.

Secara garis besar, ditinjau dari teori Allan dan Burridge (1991, h. 14-31), pembentukan ekspresi-ekspresi disfemisme sama dengan pembentukan ekspresi-ekspresi eufemisme yakni sebagai berikut:

1) Ekspresi figuratif, antara lain; metafora, contoh: "Hear the dogs howling out of the key", flippansi atau ucapan sembrono, contoh:"You were Dead from the Git-Go!"; pemodelan kembali, contoh: "Shoot!" dari "Shit!" atau "Darn it!" dari "Damn it!"; simile, contoh "But she looks like hell to me";ironi, contoh: "Well maybe I'm the faggot America."

2) Sirkumlokusi, contoh: "Shit out of luck" dan pemendekan, contoh: "fags" untukfaggots.

3) Singkatan, contoh: "SNAFU" kependekan dari Situation Normal All Fucked Up, "GRID" kependekan dariGay Related Immuno-Deficiency, dan abreviasi "SOS" kependekan dariShit on Shingle, dan "SOB" kependekan dariSon of Bitch.

4) Omisi, sensor atau penghilangan seluruh atau sebagian kata, contoh: $f^{* * *}, d^{*} m n$.

5) Synecdoche totem pro parte (seluruh untuk sebagian), contoh:"person" untuk penis; dan synecdoche pars pro toto (sebagian untuk seluruh ), contoh: "tits" untuk payudara atau "He's a prick!", metonymy, contoh: "Dickhead", "Fuckface".

6) Hiperbola, contoh: "He's the rottenest bastard I ever come across", "You great prick!", dan litotes "If you could just spare me a FEW moments of your time..." FEW disini mengandung makna sarkastis.

7) Penggunaan istilah teknis dan jargon, contoh teroris, komunis, dan penggunaan istilah sehari-hari misalkan "Junk" dan "crippled".
8) Penggunaan istilah yang dipinjam dari bahasa lain, misalkan "skepsel creature" untuk kaum berkulit hitam atau ras Negro (digunakan untuk tujuan diskriminasi ras), "kriechend" untuk kaum Yahudi (digunakan pada masa NAZI).

Pada level sosial kemasyarakatan, bahasa mempunyai beberapa fungsi. Beberapa bahasa juga digunakan untuk berperan dalam fungsi identifikasi sosial dalam masyarakat dengan menyediakan indicator-indikator linguistik, yang dapat digunakan untuk memperkokoh stratifikasi sosial. Fitur-fitur kebahasaan secara sadar maupun tidak digunakan oleh manusia, sehingga dapat menunjukkan identitas penutur dan petutur, sehingga dapat menjadi penanda kategori dan stratifikasi sosial mereka serta menjaga keragamannya. Lebih lanjut, Hymes dalam Saville-Troike (1982, h. 15-16) juga menyatakan bahwa pada level individu dan kelompok yang saling berinteraksi, fungsifungsi penggunaan bahasa sebagai alat komunikasi secara langsung bergantung pada tujuan dan keinginan pengguna bahasa tersebut.

Secara umum, penutur mempunyai dua macam motif penggunaan ekspresi-ekspresi disfemistis untuk memperbincangkan suatu topik tertentu. Pertama, untuk menghina atau menistakan citra orang yang dituju. Kedua, untuk memaksimalkan luka atau sakit pada orang yang dituju. Dalam hal ini, disfemisme juga digunakan untuk beberapa maksud, yakni untuk menunjukkan kemarahan, frustasi, ketidaksukaan, penghinaan, ejekan, atau respon atas sesuatu yang tidak diinginkan dan diharapkan.

Karsana (2015, h. 149) menyatakan bahwa fungsi makian dalam bahasa Kaili yaitu sebagai alat untuk mengekspresikan emosi yang meliputi kemarahan, kekesalan, keheranan, penghinaan atau merendahkan orang lain, keterkejutan, rasa humor, dan ancaman atau peringatan.

Secara khusus Laili (2005) menjelaskan fungsi penggunaan disfemisme dapat dibedakan sebagai berikut, yaitu: (1) menyakiti orang yang dituju, (2) menuduh atau menggugat (3) penolakan atau pengingkaran terhadap seseorang atau sesuatu hal, (4) janji atau sumpah (5) mengkritik (6) memberi pertanyaan (7) 
mengutuk atau melaknat (8) meyakinkan petutur (9) mengekspresikan ketidakpedulian (10) mengekspresikan pembangkangan.

Selain itu, sebagaimana yang dipaparkan oleh Ljung (2006, h. 60-61), makian yang mengandung disfemisme memiliki fungsi sebagai berikut:

\begin{tabular}{ll}
\multicolumn{1}{c}{ Tabel 2. Fungsi Makian atau Disfemisme } \\
\hline \multicolumn{1}{c}{ Fungsi } & \multicolumn{1}{c}{ Contoh } \\
\hline $\begin{array}{l}\text { Seruan karena kaget } \\
\text { atau terganggu }\end{array}$ & shit!, fuck!, damn! \\
\hline Sumpah & $\begin{array}{l}\text { i'll be damn! screw me if... burn in } \\
\text { hell! }\end{array}$ \\
\hline $\begin{array}{l}\text { Setuju dan } \\
\text { ketidaksetujuan }\end{array}$ & $\begin{array}{l}\text { he damned well did it! you know } \\
\text { bloody well i do! in my ass! you bet } \\
\text { your ass } \text { i will! like hell it is! }\end{array}$ \\
\hline Kutukan atau laknat & goddamn you! to hell with it! \\
\hline Saran yang kasar & $\begin{array}{l}\text { go to hell! go fuck yourself! get } \\
\text { lost! kiss my ass! }\end{array}$ \\
\hline $\begin{array}{l}\text { Menghina, mencaci } \\
\text { atau menista }\end{array}$ & $\begin{array}{l}\text { your mama... your momma's so fat } \\
\text { smaller objects orbit her! }\end{array}$ \\
\hline $\begin{array}{l}\text { Kata-kata yang } \\
\text { melecehkan }\end{array}$ & $\begin{array}{l}\text { asshole! shitface! cunt! wanker! } \\
\text { dickhead! fuckface! motherfucker! } \\
\text { bitch! basterd! son of a bitch! }\end{array}$ \\
\hline $\begin{array}{l}\text { Penegasan atas } \\
\text { ketidaksukaan }\end{array}$ & every fucking time! life's a bitch! \\
\hline $\begin{array}{l}\text { Meningkatkan } \\
\text { intensitas } \\
\text { disfemisme }\end{array}$ & $\begin{array}{l}\text { its fucking incredible! she's bloody } \\
\text { smart! it scares me shitless! i work } \\
\text { my ass off! }\end{array}$ \\
\hline $\begin{array}{l}\text { Memberi penekanan } \\
\text { atau penguatan atas } \\
\text { seruan }\end{array}$ & $\begin{array}{l}\text { no fucking way! fucking stupid! } \\
\text { shut the fuck up! ala-fucking- } \\
\text { bama! }\end{array}$ \\
\hline $\begin{array}{l}\text { Memberi penekanan } \\
\text { atau penguatan atas } \\
\text { pertanyaan }\end{array}$ & $\begin{array}{l}\text { what the hell do you mean? who } \\
\text { the fuck are you? } \\
\text { Makian } \\
\text { balls to do that! }\end{array}$ \\
\hline
\end{tabular}

Dapat disimpulkan bahwa beberapa fungsi penggunaan disfemisme bersifat kasar, tidak sopan, dan menistakan pendengarnya, baik itu orang yang dituju maupun pihak ketiga sebagai orang yang mendengar dan terlibat dalam komunikasi. Namun, yang perlu digarisbawahi kembali, penggunaan disfemisme tergantung pada konteks, waktu, dan tempat dilakukannya proses komunikasi.

\section{Keterkaitan Eufemisme, Disfemisme dan Ortofemisme}

Terdapat keterkaitan penggunaan ekspresi-ekspresi tertentu berdasarkan pemilihan kata yang digunakan oleh penutur, yaitu eufemisme, disfemisme dan ortofemisme. Eufemisme adalah ungkapan manis, sangat halus, atau ekspresi yang lebih patut diungkapkan untuk menjaga komunikasi yang baik serta menjaga muka penutur, petutur dan pendengar. Ortofemisme adalah ungkapan yang lebih netral tanpa bermaksud mempermanis, atau terlampau sopan seperti eufemisme, namun juga tidak kasar dan menyakitkan penutur, petutur dan pendengar. Jadi, eufemisme dan ortofemisme berkonotasi positif bagi penutur, petutur, dan pihak ketiga yang menjadi pendengar (Allan dan Burridge, 2006).

Ortofemisme dan eufemisme adalah kata-kata atau frase yang digunakan sebagai alternatif yang digunakan untuk menghindari ekspresi-ekspresi yang tidak patut diucapkan. Keduanya digunakan untuk menghindari kehilangan muka dalam berkomunikasi, baik antara penutur, petutur, atau orang yang menjadi pendengar. Dapat disimpulkan bahwa ortofemisme dan eufemisme merupakan strategi untuk mengungkapkan kesantunan.

Allan dan Burridge (2006, p. 33) menyimpulkan bahwa ortofemisme dan eufemisme timbul baik atas kesadaran maupun ketidaksadaran sensorik diri. Keduanya digunakan penutur untuk menghindari perlakuan yang mempermalukan atau menyakiti petutur dan orang ketiga yang menjadi pendengar, sebagai upaya penutur dalam menjaga kesantunan. Perbedaan antara kedua istilah tersebut yakni sebagai berikut: Ortofemisme lebih formal, langsung, lugas dan eksplisit daripada eufemisme. Sedangkan eufemisme lebih implisit, tidak langsung, atau metaforis dan mengandung makna kias.

Allan dan Burridge (1991, p. 5) juga menegaskan bahwa ketidaksantunan lebih mudah dilihat daripada kesantunan. Karena perilaku tidak sopan cenderung menyakitkan, maka disebut disfemistis. Sedangkan disfemisme adalah kebalikan dari eufemisme. Disfemisme tidak menjaga muka, tetapi justru merusak muka penutur, petutur, dan orang ketiga yang mendengarkan.

Allan dan Burridge (2006, p. 33-34) menyarankan istilah teknis untuk penyebutan ortofemisme, eufemisme dan disfemisme sebagai X-femisme, dan digambarkan dalam ilustrasi sebagai berikut: 


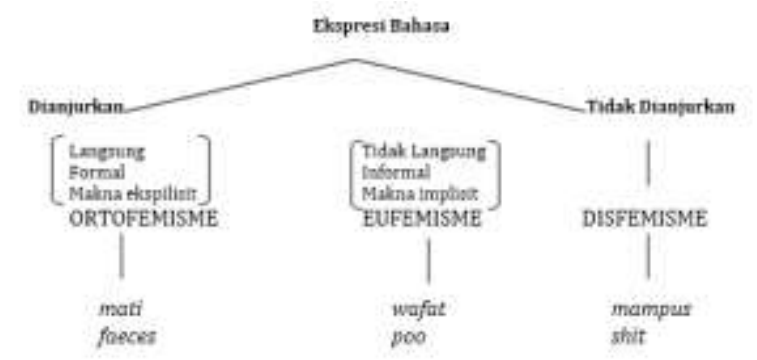

Gambar 1. Hubungan Eufemisme, Disfemisme dan Ortofemisme

Penggunaan X-femisme tersebut bergantung pada konteks, tempat, dan waktu. Misalkan istilah mampus bisa menyakitkan bagi sebagian besar petutur dan pendengar. Namun, jika istilah ini digunakan dalam komunitas tertentu, misalkan bar, kuli bangunan, buruh, maka istilah tersebut tidak disfemistis karena mampus digunakan untuk bercanda dan menunjukkan keakraban. Pada suasana keakraban, baik penutur, petutur maupun pendengar merasa nyaman dan tidak terganggu atau tersakiti. Karena itu, dapat ditarik kesimpulan bahwa penggunaan Xfemisme bergantung pada konteks, yaitu topik apa yang sedang dibahas, dimana tempat terjadi komunikasi, dan kapan ekspresiekspresi X-femisme dituturkan. Konotasi yang dihasilkan akan berbeda dari konteks yang satu dengan konteks lainnya, komunitas satu dengan lainnya, dan tentu saja, dari individu satu dengan individu lainnya (Allan dan Burridge, 2006, h. 35).

\section{Disfemisme dalam Semantik dan Sosiolinguistik}

Goffman dalam Renkema (1993, h. 13) memperkenalkan konsep 'face' atau muka yang dimaksudkan untuk image atau citra seseorang dalam menjalin hubungan sosial dengan sesama manusia. Dalam pandangan Goffman, setiap pelaku hubungan sosial, tentu memerlukan apresiasi atau penghargaan oleh orang lain. Mereka juga membutuhkan kebebasan dan tidak diganggu. Goffman menyebut kebutuhan untuk diapresiasi sebagai 'positive face' atau muka positif. Sedangkan kebutuhan untuk tidak diganggu disebut 'negative face' atau muka negatif.

Brown dan Levinson (1987) mengatakan bahwa teori tentang strategi kesantunan dikembangkan untuk menjaga muka para pendengar. Menjaga muka dimaksudkan untuk menghormati baik penutur, petutur, maupun pendengar, dan menjaga kehormatan diri dalam situasi percakapan publik. Dalam hal ini, penutur diharapkan untuk menghindari perlakuan yang mempermalukan orang lain (terutama petutur), maupun membuat orang lain (petutur dan pendengar) merasa tidak nyaman. Face Threatening Acts (FTAs) atau tindakan memelihara muka adalah tindakan yang bertujuan untuk menjaga citra baik penutur maupun pendengar, dan terutama bertujuan untuk menghormati lawan bicara serta pendengar di sekitar peristawa tutur. Strategi kesantunan terutama dikembangkan untuk tujuan FTAs atau menjaga muka.

Goffman dalam Wardaugh (2002, h. 275) menyatakan bahwa kesantunan adalah perilaku menjaga interaksi sosial dengan memainkan drama mini untuk menjaga muka baik penutur maupun petutur. Dalam hal ini, manusia memainkan peran sebagai makhluk yang mempunyai peran dalam kehidupan sosial. Dapat disimpulkan bahwa Goffman memperkenalkan teori tentang menghargai orang lain dalam hal keyakinan, pendapat, dan sebagainya, dengan berdasarkan kepada hak asasi manusia tanpa melanggar aturan dan norma sosial tentang tingkah laku.

Grundy (2000, h. 146) menyatakan bahwa fenomena kesantunan adalah salah satu manifestasi dari konsep etika dalam artian yang lebih luas, atau tingkah laku yang patut dilakukan manusia. Dari pernyataan ini, dapat dikatakan bahwa manusia mempunyai etika atau tingkah laku yang patut dalam lingkup kehidupan sosial. Sebagaimana yang kita ketahui dalam masyarakat yang majemuk, terdapat bermacam budaya yang tentu mempengaruhi konsep kesantunan pada masing-masing kelompok masyarakat (suku, etnis, subkultur, atau komunitas). Jadi, etika menurut masing-masing kelompok masyarakat pun juga berbeda. Walau demikian, pada dasarnya, setiap manusia di dunia tentu ingin diperlakukan secara santun.

Dalam hal ini, Allan dan Burridge (2006, h. 53-54) mendefinisikan kesantunan dalam hal-hal yang bersifat tidak menyinggung, dan mengkategorikan ortofemisme dan eufemisme di dalamnya. Sedangkan ketidaksantunan dan disfemisme merupakan kebalikannya dari segi negatif. Ketidaktersinggungan tersebut dapat pula didefinisikan sebagai citra sebagaimana 
yang diinginkan oleh setiap orang, atau disebut citra diri publik yang ideal.

Topik tentang disfemisme merupakan pelanggaran terhadap prinsip-prinsip kesantunan yang berkaitan erat dengan muka dan efek yang ditimbulkan. Disfemisme juga melanggar prinsip tabu dalam ranah sosiolinguistik, yakni ungkapan terlarang pada suatu masyarakat. Penggunaan disfemisme menjadikan hal-hal tabu pada masa lalu menjadi hal yang biasa dan wajar diungkapkan pada masa sekarang.

\section{Disfemisme dan Analisis Wacana}

Menurut Foucault dalam Eriyanto (2001, h. 65-113), wacana tidak hanya dipahami sebagai serangkaian kata atau proposisi dalam teks tetapi sesuatu yang memproduksi yang lain (sebuah gagasan, konsep, atau efek). Wacana dapat dideteksi karena secara sistematis suatu ide, opini, konsep, dan pandangan hidup dibentuk dalam suatu konteks tertentu sehingga mempengaruhi cara berpikir dan bertindak tertentu. Wacana secara ideologi dapat menggusur gagasan orang atau kelompok tertentu dengan menggunakan teks sebagai sarana sekaligus media melalui mana satu kelompok mengunggulkan diri dan memarjinalkan kelompok lain. Dalam hal ini, bahasa memiliki peran penting dalam representasi, yakni bagaimana seseorang, satu kelompok, gagasan, atau pendapat tertentu ditampilkan dalam pemberitaan.

Dalam bahasa tulis, representasi ditunjukkan dengan penggunaan kata, kalimat, atau proposisi, grafik, caption, dan sebagainya. Contoh representasi wacana dalam bahasa tulis adalah dokumen, teks wawancara, transkrip, dan lain-lain. Elemenelemen tersebut kemudian ditansmisikan ke dalam kode representasional yang memasukkan bagaimana objek digambarkan (karakter, narasi, setting, dialog, dan lain-lain). Kemudian, semua elemen tersebut diorganisasikan dalam koherensi sosial dan kode-kode ideologi yang terdapat dalam masyarakat seperti individualisme, liberalisme, sosialisme, patriarki, ras, kelas, materialisme, kapitalisme, dan sebagainya. (Eriyanto, 2001, h. 114-116).

Dari sini, terbentuklah kepercayaan sosial yang seringkali diterima sebagai common sense oleh khalayak Common sense pula yang kemudian acapkali diserap sebagai realitas oleh masyarakat. Dalam membentuk realitas ini, media memiliki dua peran yang sangat penting. Pertama, pemilihan fakta yang didasarkan pada asumsi wartawan yang tidak mungkin melihat suatu peristiwa tanpa perspektif. Kedua, bagaimana fakta tersebut dipilih untuk disajikan kepada khalayak dengan menggunakan kata, kalimat, proposisi, kemudian dilengkapi dengan foto, gambar dan data lain (Eriyanto, 2001, h. 116).

Dalam representasi ini, sangat mungkin terjadi misrepresentasi, yaitu ketidakbenaran penggambaran atau kesalahan penggambaran. Seseorang, suatu kelompok, suatu pendapat, atau gagasan tidak ditampilkan sebagaimana mestinya, tetapi digambarkan secara buruk. Secara umum, ada empat misrepresentasi yang mungkin terjadi dalam pemberitaan (Eriyanto, 2001, h. 120-130).

1. Ekskomunikasi, yaitu bagaimana seseorang atau sekelompok orang dikeluarkan dari pembicaraan publik dan tidak diperkenankan untuk berbicara dan terlibat dalam diskursus publik. Ciri pertama, partisipan wacana hanya dibatasi pada pihak kita. Ciri kedua, penggambaran selalu dalam rangka kepentingan kita.

2. Eksklusi, yaitu bagaimana seseorang, gagasan, atau kelompok dikeluarkan dari pembicaraan publik namun untuk dikucilkan. Ciri pertama, pembatasan atas apa yang bisa dan tidak bisa didiskusikan, siapa yang boleh dan tidak boleh berbicara. Ciri kedua, pengklasifikasian mana yang baik, mana yang buruk, mana yang bisa diterima, dan mana yang tidak bisa diterima. Wacana yang dihasilkan disini, adalah kita baik (termasuk apa yang kita bicarakan), sedangkan mereka (yang dikucilkan) buruk.

3. Marjinalisasi, yaitu penggambaran buruk kepada pihak/kelompok lain. Sedikit berbeda dengan ekskomunikasi dan eksklusi yang memposisikan pihak lain sebagai the others, marjinalisasi tidak memilah antara pihak kita dan pihak yang lain. Praktek marjinalisasi dalam media yakni dengan menggunakan praktik pemakaian bahasa eufemisme, disfemisme, labeling, dan stereotipe. Penjelasan selengkapnya lihat di bawah. 
4. Delegitimasi, yaitu penekanan bahwa hanya kelompok kami yang benar, sedangkan kelompok lain tidak benar, tidak layak dan tidak absah. Ciri pertama, dilakukan dengan otoritas seseorang yang menekankan bahwa hanya mereka yang layak berbicara, merasa absah dan punya otoritas intelektual tertentu. Ciri kedua, legitimasi wacana bukan hanya berurusan dengan siapa yang absah dan siapa yang tidak, tetapi juga apakah suatu pernyataan tersebut absah atau tidak, dengan cara memakai istilah teknis, alasan formal, yuridis, atau berbau ilmiah, sehingga argumentasi yang dikemukakan terlihat benar, masuk akal, dan ilmiah.

Dapat disimpulkan, penggunaan disfemisme merupakan salah satu cara misrepresentasi, yakni dalam poin marginalisasi wacana. Berbeda dengan eufemisme yang merupakan penghalusan makna serta digunakan untuk menyebut tindakan yang dilakukan kelompok deminan, disfemisme yang merupakan pengasaran makna, umumnya digunakan untuk menyebut tindakan yang dilakukan oleh masyarakat bawah. Eufemisme lebih digunakan untuk menipu, mengaburkan dan mengabstraksikan realitas. Sedangkan disfemisme lebih digunakan untuk memperburuk dan membuat realitas orang dibicarakan menjadi kasar, tidak sah, tidak benar, atau bahkan salah.

Labeling membuat posisi kelompok atau kegiatan menjadi terlihat buruk dan salah. Stereotipe atau penyamaan sebuah kata yang menunjukkan sifat-sifat negatif atau positif (tetapi umumnya negatif), tentang orang, kelompok, kelas, atau tindakan. Stereotipe menggambarkan sesuatu yang penuh prasangka, konotasi negatif dan bersifat subjektif. Sehingga pada akhirnya, stereotipe sering digunakan kelompok tertentu untuk menggambarkan kelompok lain secara negative atau buruk. Jika merujuk dari Allan dan Burridge (1991), maka labeling dan stereotipe yang negatif yang terdapat dalam poin marjinalisasi di atas, juga termasuk disfemisme karena ofensif kepada orang yang dituju, maupun khalayak yang menjadi pendengar.

\section{KESIMPULAN}

Dapat ditarik kesimpulan bahwa kesantunan diterapkan pada setiap masyarakat walaupun aturan dan realisasinya berbeda. Setiap masyarakat mempunyai perilaku verbal dan aksi masing-masing, tetapi konsep kesantunan dalam pikiran semua manusia tetaplah sama. Dengan kata lain, pada hakikatnya semua manusia ingin berlaku dan diperlakukan dengan santun. Eufemisme menjadi salah satu cara untuk mengungkapkan kesantunan. Sebaliknya, disfemisme menjadi salah satu cara untuk mengungkapkan ketidaksantunan, karena menyakiti muka orang yang dituju dan pendengar sebagai pihak ketiga yang turut terlibat dalam proses komunikasi tersebut.

Dalam ranah semantik, disfemisme termasuk dalam ruang lingkup konotasi dan perubahan makna. Dalam ranah sosiolinguistik, disfemisme termasuk dalam ruang lingkup bahasan eufemisme dan tabu. Sedangkan dalam ranah analisis wacana, disfemisme termasuk dalam ruang lingkup interaksi sosial dan wacana, konteks dan makna dan kesantunan serta bahasa dalam media.

\section{DAFTAR PUSTAKA}

Allan, Keith. (2001). Natural Language Semantics. Wiley-Blackwell Publishers

Allan, Keith and Kate Burridge. (1991). Euphemism and Dysphemism: Language Used as Shield and Weapon. New York: Oxford University Press

Allan, Keith and Kate Burridge. (2006). Forbidden Words: Taboo and the Censoring of Language. New York: Oxford University Press

Allan, Keith and Kate Burridge. (2009). "Euphemism, Dysphemism, and Cross-Varietal Synonymy: Academic". Makalah diakses pada tanggal 26 Desember 2016 di laman 
www.latrobe.edu.au/linguistics/LaTrobePapersinLinguistics/Vol\%2001/1AllanandBurridge. pdf

Crystal, David. (1987). "The Functions of Language," dalam The Cambridge Encyclopedia of Language. Cambridge: Cambridge University Press

Eriyanto. (2001). Analisis Wacana: Pengantar Analisis Teks Media. Yogyakarta: LKiS

Grundy, Peter. (2000). Doing Pragmatics. London: Arnold Publishing

Holmes, Janet. (1992). An Introduction to Sociolinguistics. Britain: Pearson Longman

Indrawati, Dianita. (2006). "Makian dalam Bahasa Madura". Disertasi. Denpasar: Universitas Udayana

Renkema, Jan. (1993). Discourse Studies: an Introductory Textbook. Philadelphia: John Benjamins Publishing Company

Johnstone, Barbara. (2002). Discourse Analysis. Wiley-Blackwell Publishers

Karsana, Deni. "Referensi dan Fungsi Makian dalam Bahasa Kaili" dalam Metalingua Vol. 13, No. 2, Desember 2015. Hal: 141-150

Karjalainen, Markus. (2002). "Where Have All the Swearwords Gone? An Analysis of the Loss of Swearwords in Two Swedish Translations of J. D. Salinger's Catcher in the Rye". Unpublished Thesis. Helsinki: University of Helsinki

Laili, Elisa Nurul. (2005). “Dysphemism Used in Greenday's and Slipknot Lyrics”. Skripsi yang Tidak Diterbitkan. Malang: Universitas Islam Negeri Malang

Ljung, Magnus. (2006). Svordomsboken. Terj. Uddevala: Nordstedts Akademiska Forlag

Masrokhin. (2002). "A Sociolinguistics Study on the Rude Words Used by the Street Children in Malang". Skripsi yang Tidak Diterbitkan. Malang: Universitas Islam Negeri Malang

Saville-Troike. (1982). The Ethnography of Communication. Oxford: Basil Blackwell

Wardaugh, Ronald. (2002). Introduction to Sociolinguistics: Fourth Edition. Oxford: Blackwell Publishers

Wijana, I Dewa Putu. (1997). "Pragmatik dan Pembelajaran Bahasa Asing”.Humaniora, No. 5, Hal. 26-30, Yogyakarta: Fakultas Sastra Universitas Gadjah Mada

Wijana, I Dewa Putu. "Kata-kata Kasar dalam Bahasa Jawa" dalam Humaniora vol. 20, No.3. Oktober 2008. Hal. 249-256, Yogyakarta: Fakultas Sastra Universitas Gadjah Mada

Wijana, I Dewa Putu dan Rohmadi. (2006). Sosiolinguistik: Kajian Teori dan Analisis. Cet. 2. Yogyakarta: Pustaka Pelajar. 